\title{
Managing Pestiferous Freshwater Aquatic Midge Emergences From Storm Water Retention Ponds ${ }^{1}$
}

\author{
Kenneth T. Gioeli, Philip G. Koehler, R. Leroy Creswell, Jeffrey P. Gellermann, and Edward A. \\ Skvarch $^{2}$
}

Freshwater aquatic midges are mosquito-like Diptera belonging to the families Chironomidae and Chaoboridae (Koehler, 2003). Chironomidae are commonly referred to as "Blind Mosquitoes" and Chaoboridae are commonly referred to as "Phantom Predatory Midges" (Figure 1). Midge eggs, larva, and pupa are often found in storm water retention ponds, and their larvae thrive in low oxygen zones. These larvae are often referred to as wrigglers, and sometimes as "bloodworms" because some are bright red in color (Figure 2). The adult midges do not bite, suck blood, or carry diseases, and therefore are sometimes called "blind mosquitoes." Adult midges become a problem when they emerge from ponds in large numbers, primarily in the warm summer months (Figure 3).

Unfortunately, the emergence of large numbers of these pestiferous aquatic midges impacts the quality of life of the residents living around many storm water retention ponds in communities throughout Florida. Adult midges prefer to rest in shady areas in the day and are often found in large numbers under eaves, on patio screens, and in foyers.

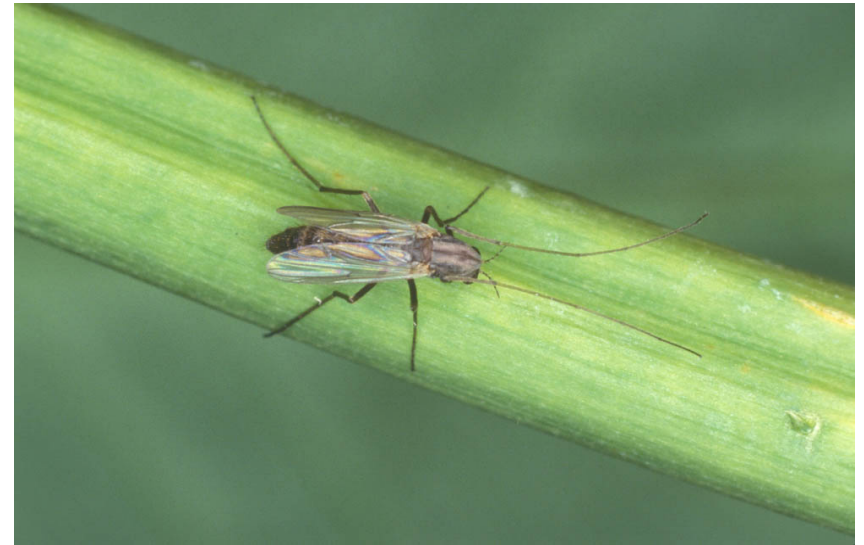

Figure 1. Chironomid Adult. Credits: James Castner, University of Florida

These midges can also find their way inside homes as residents enter and exit the structure. In addition, people have reported damage to paint finishes, airplanes, allergies and discouraged tourism.

A Freshwater Aquatic Midge Integrated Pest Management (FAM IPM) Plan has been developed by the University of Florida to help residents tackle these midge problems. IPM plans are described as a coordinated use of multifaceted pest control

1. This document is ENY-856 (IN825), one of a series of the Entomology and Nematology Department, Florida Cooperative Extension Service, Institute of Food and Agricultural Sciences, University of Florida. Publication date: October 2009. Please visit the EDIS website at http://edis.ifas.ufl.edu.

2. Kenneth T. Gioeli, natural resources extension agent, R. Leroy Creswell, sea grant extension agent, Jeffrey P. Gellermann, Edward A. Skvarch, St. Lucie County Cooperative Extension, University of Florida, Ft. Pierce and Philip G. Koehler, professor, Entomology \& Nematology Department, University of Florida, Gainesville. FL. 


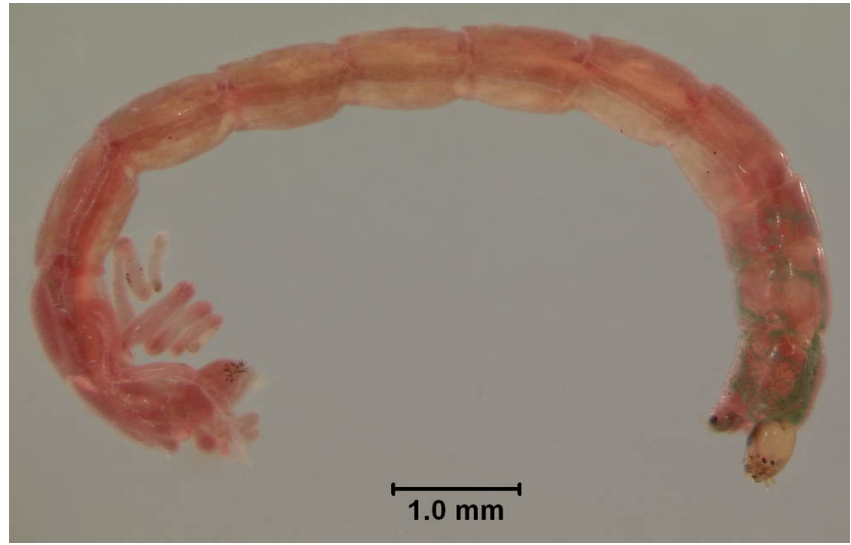

Figure 2. Bloodworm. Credits: Lyle Buss, University of Florida

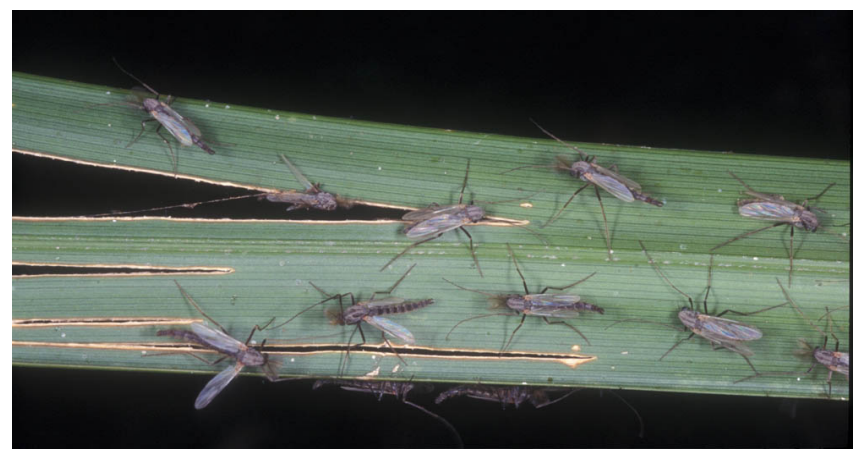

Figure 3. Family: Chironomidae; Genus: Glyptotendipes. Credits: Lyle Buss, University of Florida

strategies. The FAM IPM Plan features the coordinated use of algae control strategies, insectivorous fish, light traps, and insect growth regulators.

\section{Healthy Ponds}

The residents concept of what constitutes a healthy, desirable pond can be taken into account when designing a local FAM IPM Plan. These considerations may include fertilizer and pesticide-free buffers between turf and ponds edge; clean, clear water with no algae and low turbidity; irregular shaped ponds with appropriate native, low maintenance vegetation; and adequate fish and wildlife.

\section{Aquatic Midge IPM Plan}

The first strategy in the FAM IPM plan involves the use of algae control. Larval Chironomidae graze on algal detritus that settles to the bottom of these ponds. Ponds can be treated with algaecides, such as those containing copper, to control algae. A nutrient abatement strategy should also be implemented. This strategy involves the enforcement of the Florida Green Industry Standards for fertilizer application to turf around ponds. According to the Florida Department of Environmental Protection (2002), for flat turf, adopt the use of three foot untreated buffers if a fertilizer spreader with a deflector shield is used or a ten foot untreated buffer if a spreader without a deflector shield is used. For steeply sloped turf, larger buffers are recommended. Other environmentally friendly practices such as avoiding blowing grass clippings into the water and using slow release fertilizers are also featured in the nutrient abatement strategy.

The second strategy in the FAM IPM plan involves the use of insectivorous fish to biologically control aquatic midges in ponds. Ponds can be stocked with bream and bass to control nuisance aquatic insects and provide recreational fishing opportunities. According to the Florida Fish and Wildlife Conservation Commission (2007), bream should be stocked at a rate of five hundred fingerlings per acre. Bream (70\% blue gill / 30\% red ear) should be stocked in the fall, allowing them to spawn. One hundred bass fingerlings per acre were stocked in the spring when feeder fish were available. Stocking in the summer is not recommended as high temperatures can potentially stress the fish (Cichra, 1995).

The third strategy in the FAM IPM plan involves the use of light traps to control adult midges (Ali et al., 1994). Some light traps are able to either trap or kill midges to reduce their numbers. Lights can be used in upland buffers adjacent to the infested ponds in order to divert midges from houses.

The fourth strategy in the FAM IPM plan involves the use of insect growth regulators (IGRs) to prevent midge larvae from pupating normally and developing into the adult stage. An IGR labeled for the control of aquatic midges contains (S)Methoprene and is sold in pellets. These pellets release the IGR for up to 30 days. (S)-Methoprene can effectively stop the formation of midge pupae in the water (Ali, 1991). The (S)-Methoprene label 
recommends a dosage of five to ten pounds per acre which should be applied twenty feet from the waters edge. Always read and follow label directions. Although the use of (S)-Methoprene can effectively manage aquatic midge pupae, it can be expensive.

\section{Conclusion}

Implementation of the FAM IPM Plan should result in a significant reduction of pestiferous aquatic midge emergences from storm water retention ponds. An integrated use of algae control strategies, insectivorous fish, light traps, and insect growth regulators can be effective if properly implemented.

\section{References}

Ali, A. (1991). Perspectives on management of pestiferous Chironomidae (Diptera), an emerging global problem. J. Am. Mosq. Control Assoc. 7:260-281.

Ali, A., Ceretti, L. Barbato, G. Marchese, F. D'Andrea, \& B. Stanley. (1994). Attraction of Chironomus salinarius (Diptera: Chironomidae) to artificial light on an island in the saltwater lagoon of Venice, Italy. J. Am Mosq. Control Assoc. 10:35-41.

Cichra, C. (1995). Managing Florida ponds for fishing. Univ. of Fla / IFAS Circular 802.

Department of Environmental Protection. (2002). Summary of Florida Green Industries Best Management Practices for Protection of Water Resources in Florida.

Florida Fish and Wildlife Conservation Commission. (2007). Producers of fish for stocking purposes. Retrieved March 27, 2008, from: http://www.myfwc.com/Fishing/docum/fish-sup.html

Koehler, P. (2003). Blind Mosquitoes (Aquatic Midges). Univ. of Fla. / IFAS. Retrieved March 27, 2008, from: http://edis.ifas.ufl.edu/IG092. 